\title{
Determination and Distribution Study of Pogostone in Rat Tissues by Ultra-Fast Liquid Chromatography
}

\author{
Hai-ming Chen ${ }^{1,2}$, Lan Wang ${ }^{2}$, Xiao-li Wu ${ }^{1,3}$, Chu-wen $\mathrm{Li}^{1,4}$, You-liang Xie ${ }^{1}, \mathrm{Yu}$ - \\ hong Liu ${ }^{1}$, Yong-zhuo Liang ${ }^{1}$, Xiao-ying Chen ${ }^{1}$, Xiao-ping Lai ${ }^{1,5}$, Jian-nan \\ Chen $^{1,5}$, Yu-cui Li ${ }^{1 *}$ and, Zi-ren Su ${ }^{1,5 *}$ \\ ${ }^{1}$ College of Chinese Medicines, Guangzhou University of Chinese Medicine, Guangzhou 510006, ${ }^{2}$ The First Affiliated Hospital \\ of Chinese Medicine, Guangzhou University of Chinese Medicine, Guangzhou 510405, ${ }^{3}$ Faculty of Health Sciences, University \\ of Macau, Macau 999078, ${ }^{4}$ State Key Laboratory of Quality Research in Chinese Medicine, Institute of Chinese Medical \\ Sciences, University of Macau, Macau 999078, ${ }^{5}$ Dongguan Mathematical Engineering Academy of Chinese Medicine, \\ Guangzhou University of Chinese Medicine, Dongguan 523808, China
}

*For correspondence: Email: liyucui@gzucm.edu.cn, suziren@gzucm.edu.cn; Tel: +86 20 39358517; Fax: +86 2039358390

\begin{abstract}
Purpose: To develop and validate a rapid, sensitive and reliable ultra-fast liquid chromatography (UFLC) method with photodiode array (PDA) detection for the determination of pogostone (PO) in rat tissues using honokiol as internal standard (IS).

Methods: Rats were randomly divided into two groups (intravenous administration group and oral administration group) and given of a single dose of $10 \mathrm{mg} / \mathrm{kg} P O$ by intravenous administration and oral administration, respectively. After intravenous injection, the rats were sacrificed at 15, 60 and $360 \mathrm{~min}$, while rats, after oral administration, were euthanasized at 30, 90 and $360 \mathrm{~min}$, respectively. For the analysis of the preparation, optimal chromatographic conditions were determined using Acquity UPLC BEH C18 column with acetonitrile-water containing $0.1 \%$ formic acid $(55: 45, \mathrm{v} / \mathrm{v})$ as the mobile phase, at a flow rate of $400 \mu \mathrm{L} / \mathrm{min}$. UV detection wavelength was set at $310 \mathrm{~nm}$ with temperature maintained at $30^{\circ} \mathrm{C}$.

Results: Good linear relationship of calibration curve $(r>0.9984)$ was achieved over the range of 0.1 $40 \mu \mathrm{g} / \mathrm{mL}$ for all the tissue samples. The limit of quantification (LOQ) and limit of detection (LOD) were 0.1 and $0.05 \mu \mathrm{g} / \mathrm{mL}$, respectively. This method proved to have good precision, accuracy, stability, extraction recovery and matrix effect for tissue distribution studies of $P O$ in rats.

Conclusion: The developed method is suitable for tissue distribution studies in rats following intravenous and oral administration of $P O$ at a dose of $10 \mathrm{mg} / \mathrm{kg}$.
\end{abstract}

Keywords: Ultra-fast liquid chromatography, Tissue distribution, Pogostone, Honokiol, Rats

Tropical Journal of Pharmaceutical Research is indexed by Science Citation Index (SciSearch), Scopus, International Pharmaceutical Abstract, Chemical Abstracts, Embase, Index Copernicus, EBSCO, African Index Medicus, JournalSeek, Journal Citation Reports/Science Edition, Directory of Open Access Journals (DOAJ), African Journal Online, Bioline International, Open-J-Gate and Pharmacy Abstracts

\section{INTRODUCTION}

Pogostemonis Herba, the dried aerial part of Pogostemon cablin (Blanco) Benth., has been widely used in traditional Chinese medicine for removing dampness, relieving summer-heat, exterior syndrome, stimulating appetite and arresting vomiting [1]. Pogostone (PO, $\mathrm{C}_{12} \mathrm{H}_{16} \mathrm{O}_{4}$ ), 4-hydroxy-6-methyl-3-(4-methylpentanoyl)-2H-pyran-2-one, is one of the most important biological constituents isolated from the essential oil of Pogostemonis Herba [2]. Recent studies have demonstrated that $\mathrm{PO}$ exhibits a broad range of pharmacological 
activities. It was reported that $\mathrm{PO}$ can restrain the activities of Preris rapae L., Plutella xylostella L. and Dermatophagoides farinae, and was proved to be one of the insecticidal components [3]. Moreover, PO displayed considerable activity against plant pathogenic fungi and animal pathogenic fungi during in vitro study [4], particularly against vulvovaginal candidiasis in mouse models via oral and topical administration [5]. All these activities suggested that PO played a relevant role in the treatment of Candida infections, particularly for vulvovaginal candidiasis, hence it was expected to become a novel anti-vulvovaginal candidiasis drug candidate euthanasized [5].

Pharmacokinetic and tissue distribution studies are essential components of preclinical and clinical trials for development of novel drug candidates [6]. Our previous research [5,7] has shown that PO was absorbed and eliminated rapidly in rats, while tissue distribution of $\mathrm{PO}$ has rarely been reported. It is generally accepted that the biological effects of xenobiotics are related to the forms in which they circulate and concentrate in the target tissues [8]. In addition, proper knowledge on the tissue distribution which is vital to investigate the major target sites and interpret the disposition in vivo contributes to predicting a variety of events related to the efficacy and toxicity of novel drug [9].

So far, various analytical methods have been applied to the quantification of $\mathrm{PO}$ from patchouli oil and Pogostemonis Herba including high performance liquid chromatography with UV detection (HPLC-UV) [10], gas chromatography (GC) [11] and gas chromatography-mass spectrometry (GC-MS) [12]. As far as our knowledge, HPLC method had also been applied to the determination of $\mathrm{PO}$ in the plasma of mice [5]. However, there are no published methods using ultra-fast liquid chromatography (UFLC) for the determination of $P O$ in biological samples. UFLC, which has been widely used in medicines analysis, showed great advantages over traditional HPLC for its high power in separation and analysis speed as well as providing an economic alternative to LC-MS method [13-15]. Therefore, it is of great practical meaning to establish a sensitive, reliable and rapid analytical UPLC method for the determination of PO in rat tissues.

To obtain further insight into the role of PO transporters and a better understanding of the comprehensive characterization of its tissue distribution, we sought to develop a simple, rapid and highly sensitive UFLC method for the analysis of PO in various rat tissues. The newlydeveloped method was applied to tissue distribution studies after intravenous injection and oral administration of $\mathrm{PO}\left(10 \mathrm{mgkg}^{-1}\right)$ to rats, respectively.

\section{EXPERIMENTAL}

\section{Chemicals and reagents}

PO (purity, $98 \%$ ) was isolated and purified from Pogostemonis Herba in the laboratory of Institute of New Drug Research \& Development, Guangzhou University of Chinese Medicine (Guangzhou, China). Honokiol (purity, $98 \%$ ), serving as an internal standard (IS), was purchased from National Institutes for Food and Drug Control (Beijing, China). The chemical structures of $\mathrm{PO}$ and IS are shown in Figure 1. Acetonitrile (HPLC grade) was purchased from Merck KGaA (Darmstadt, Germany), and other chemicals were of analytical grade. The ultrapure water was purified using a Milli-Q gradient water purification system (Millipore, Bedford, MA, USA).<smiles>Cc1cc(O)c(C(=O)CCC(C)C)c(=O)o1</smiles>

A

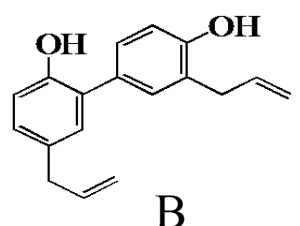

B
Figure 1: Chemical structures of pogostone $(A)$ and honokiol (B)

\section{Chromatographic system}

Chromatographic analysis was carried out with a Shimadzu LC-20A UFLC system (Shimadzu, Kyoto, Japan) equipped with a SPD-M20A PDA detector, a LC-20AT pump, a SIL-20AC automatic sampler, and a CTO-20A thermostatic column oven. The separation was performed on ACQUITY UPLC BEH C18 column $(2.1 \mathrm{~mm} \times 50$ $\mathrm{mm}$ ID, $1.7 \mu \mathrm{m}$ particles; Waters, Inc.) protected by a Van GuardTM BEH C18 guard column (2.1 $\times 5 \mathrm{~mm}$ ID, $1.7 \mu \mathrm{m}$ particles, Waters, Inc.). The samples were eluted with a mobile phase of acetonitrile-water containing $0.1 \%$ formic acid $(55: 45, \mathrm{v} / \mathrm{v})$ at a flow rate of $400 \mu \mathrm{L} / \mathrm{min}$ with a total run time of $5 \mathrm{~min}$. The column temperature was set at $30^{\circ} \mathrm{C}$. The injection volume was set at $5 \mu \mathrm{L}$ and the detection wavelength was performed at $310 \mathrm{~nm}$.

\section{Tissue distribution study}

Pogostone, accurately weighed, was dissolved in physiological saline and the $\mathrm{pH}$ was adjusted to 
8.5 with sodium hydroxide and hydrochloric acid to get a pogostone stock. Then the stock was diluted with physiological saline to get $5 \mathrm{mg} / \mathrm{mL}$ solution. Sprague-Dawley rats $(200 \pm 20 \mathrm{~g})$ were randomly divided into two groups (intravenous administration group and oral administration group) and given of a single dose of $10 \mathrm{mg} / \mathrm{kg}$ $P O$ by intravenous administration and oral administration, respectively. After intravenous injection, the rats were sacrificed at 15,60 and $360 \mathrm{~min}$, while rats after oral administration were executed at 30, 90 and $360 \mathrm{~min}$, respectively. All the experimental protocols and schedules involving animals were approved (ref. no. SYXK(YUE)2013-0085) by the Animal Welfare Committee of Guangzhou University of Chinese Medicine, and the Guidelines for Good Practice in Laboratory Animals Feeding and Management [16] was followed.

The weighed tissues (heart, liver, lung, kidney, stomach, brain, spleen or reproductive organ) were added to twice the weight of ice-cold physiological saline solution and then homogenized with the Tissue Lyser II highthroughput tissue homogenization system (Qiagen Co. Ltd, Hilden, Germany). Then $250 \mu \mathrm{L}$ IS working solution $(18 \mu \mathrm{g} / \mathrm{mL})$ and $250 \mu \mathrm{L}$ acetronitrile were immediately added into $250 \mu \mathrm{L}$ of each tissue homogenate and thoroughly vortex-mixed for $3 \mathrm{~min}$. After centrifugation at $10,000 \mathrm{rpm}$ for $10 \mathrm{~min}$, the supernatant was filtered through a $0.22 \mu \mathrm{m}$ pore-size membrane filter. Finally, $5 \mu \mathrm{L}$ aliquot of filtrate was injected into the UFLC system for analysis.

\section{RESULTS}

\section{Optimal LC conditions}

Chromatographic conditions, especially the composition of mobile phase and chromatographic column, played a critical role in achieving good chromatographic behavior. Several kinds of mobile phases, including methanol-water (containing $0.1 \%$ acetic acid or phosphoric acid or formic), acetonitrile- water (containing $0.1 \%$ acetic acid or phosphoric acid or formic) were investigated. It was found that acetonitrile-water (containing $0.1 \%$ formic acid) could achieve better peak shapes and higher sensitivities, which was thereby chosen as the mobile phase in this study. In addition, several types of chromatographic columns, including Zorbax SB-C18 column $(2.1 \times 100 \mathrm{~mm}, 3.5 \mu \mathrm{m}$ particles; Agilent, USA), YMC-Ultra HT Pro C18 column $(2.1 \times 50 \mathrm{~mm}, 2 \mu \mathrm{m}$ particles; YMC Inc., Tokyo, Japan)) and ACQUITY UPLC BEH C18 $(2.1 \times 50 \mathrm{~mm}, 1.7 \mu \mathrm{m}$ particles; Waters, Inc.
USA) were tested. It was found that ACQUITY UPLC BEH C18 $(2.1 \times 50 \mathrm{~mm}, 1.7 \mu \mathrm{m}$ particles; Waters, Inc. USA) could obtain the better separation. Hence, it was chosen as the chromatographic columns in this study. Furthermore, gradient elution was optimized to acetonitrile-water containing $0.1 \%$ formic acid $(55: 45, \mathrm{v} / \mathrm{v})$ for a total of $5 \mathrm{~min}$, while the flow rate was $400 \mu \mathrm{L} / \mathrm{min}$. Representative chromatograms of the blank tissue samples, blank tissue samples spiked with $\mathrm{PO}$ and the IS, and rat tissue samples $(1.5 \mathrm{~h}$ after oral administration of PO ) were shown in Figure 2.

\section{Linearity and sensitivity}

The calibration curves were linear over the calibration range $(0.10 \sim 40.0 \mu \mathrm{g} / \mathrm{mL})$ for $\mathrm{PO}$. The equations for the plots, the correlation coefficients, and the linear ranges for $\mathrm{PO}$ in each tissue are listed in Table 1. The results obtained demonstrated good linear relationship in all the tissues with correlation coefficients $(r>0.9984)$. LOD and LOQ were 0.05 and $0.1 \mu \mathrm{g} / \mathrm{mL}$, respectively, in the tissues.

\section{Accuracy and precision}

The results of the precision and accuracy are showed in Table 2. All results for the samples tested over the range of $-5.37 \sim 2.97 \%$ within the acceptable criteria of $\pm 15 \%$. These data demonstrated that both precision and accuracy values were within the recommended range and the method was accurate and reproducible for the determination of $\mathrm{PO}$ in rat tissue samples.

\section{Stability}

The data of stability were summarized in Table 3 , which indicated that PO was stable in room temperature for $24 \mathrm{~h}$, through repeated three freeze/thaw cycles and under the frozen condition at $-20{ }^{\circ} \mathrm{C}$ for 7 days. The results suggested that the established methods for sample extraction, storage, and intermittent analysis were validated and suited for large scale sample analysis.

\section{Recovery}

As shown in Table 4, the extraction recoveries were over the range of $94.43 \sim 101.16 \%$ for $\mathrm{PO}$, indicating that acetonitrile could offer excellent extraction efficiency for $\mathrm{PO}$ in biological tissue. 

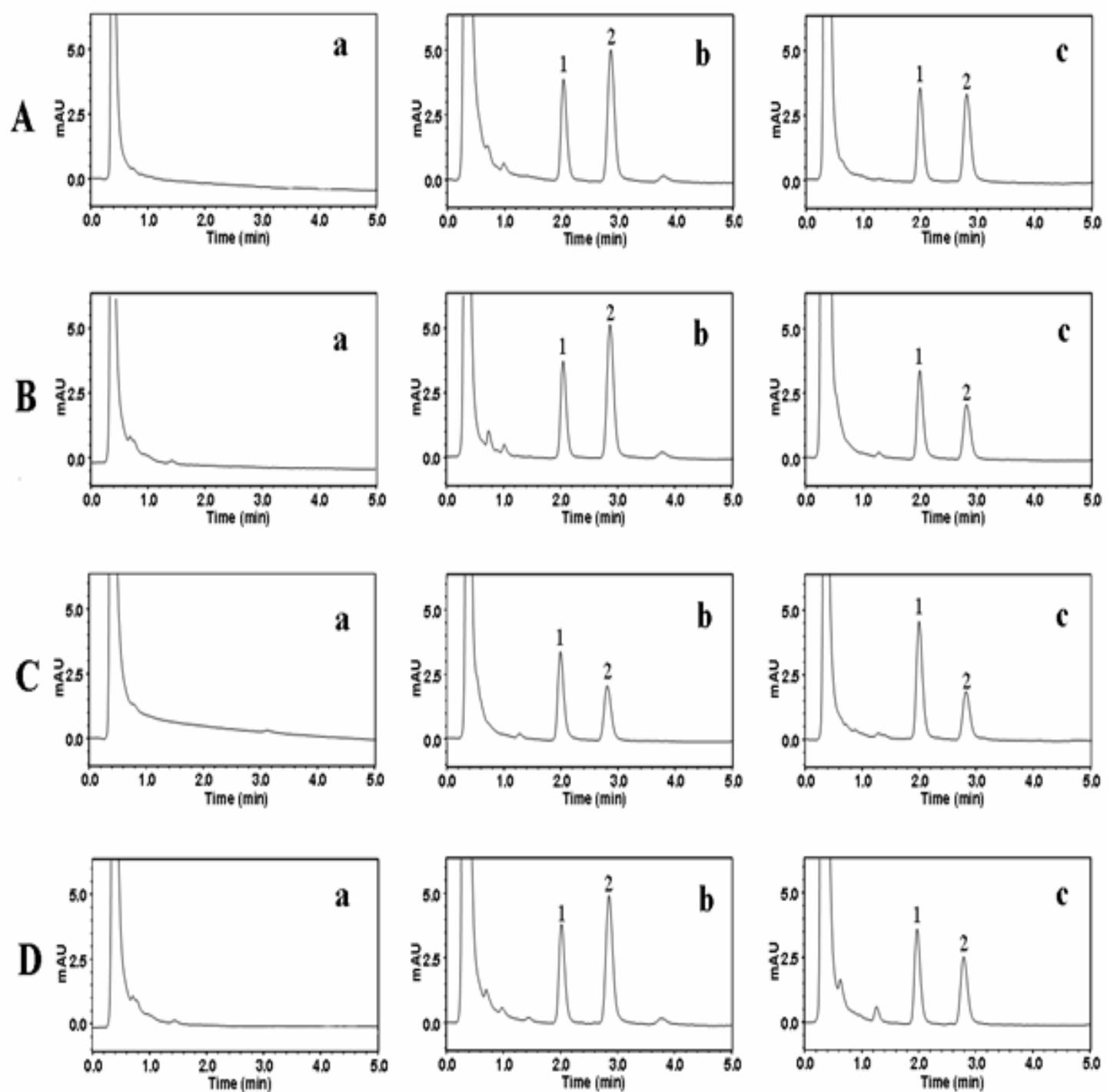

Figure 2: Typical chromatograms of pogostone from various tissues:(a) blank lung, liver, kidney and stomach tissue homogenate samples; (b) blank lung, liver kidney and stomach tissue homogenate samples spiked with pogostone and honokiol; (c) lung, liver, kidney and stomach tissue homogenate samples $1.5 \mathrm{~h}$ after oral administration of pogostone at $10 \mathrm{mg} / \mathrm{kg}$. (1: honokiol; 2: PO). Note: (A) lung tissue homogenate, (B) liver tissue homogenate, $(C)$ kidney tissue homogenate and (D) stomach tissue homogenate

Table 1: Calibration parameters for pogostone in rat tissues

\begin{tabular}{lccc}
\hline Tissue & Regression equation & $\begin{array}{c}\text { Correlation } \\
\text { coefficient }(\boldsymbol{r})\end{array}$ & Linear range $(\boldsymbol{\mu g} / \mathbf{m L})$ \\
\hline Heart & $Y=0.4104 X-0.0204$ & 0.9990 & $0.1 \sim 40$ \\
Liver & $Y=0.4152 X-0.0742$ & 0.9984 & $0.1 \sim 40$ \\
Lung & $Y=0.4108 X-0.0093$ & 0.9999 & $0.1 \sim 40$ \\
Kidney & $Y=0.3925 X+0.0362$ & 0.9993 & $0.1 \sim 40$ \\
Stomach & $Y=0.4179 X-0.0345$ & 0.9985 & $0.1 \sim 40$ \\
Brain & $Y=0.4094 X-0.0141$ & 0.9996 & $0.1 \sim 40$ \\
Spleen & $Y=0.4056 X+0.0087$ & 0.9995 & $0.1 \sim 40$ \\
Reproductive & $Y=0.4258 X-0.0454$ & 0.9991 & $0.1 \sim 40$ \\
organ & $Y$ & & \\
\hline
\end{tabular}

$Y=$ spiked concentration $(\mu \mathrm{g} / \mathrm{mL}) ; X=$ peak area 
Table 2: Precision and accuracy for the determination of pogoostne in rat tissues

\begin{tabular}{|c|c|c|c|c|c|}
\hline \multirow[b]{2}{*}{ Tissue } & \multirow{2}{*}{$\begin{array}{c}\text { Spiked } \\
\text { concentration } \\
(\mu \mathrm{g} / \mathrm{mL})\end{array}$} & \multicolumn{2}{|c|}{ Intra-day } & \multicolumn{2}{|c|}{ Inter-day } \\
\hline & & $\begin{array}{c}\text { Mean } \pm S D \\
(\mu g / m L)\end{array}$ & RSD (\%) & $\begin{array}{c}\text { Mean } \pm S D \\
(\mu g / m L)\end{array}$ & $\begin{array}{l}R S D \\
(\%)\end{array}$ \\
\hline \multirow{3}{*}{ Heart } & 0.4 & $0.49 \pm 0.02$ & 3.99 & $0.49 \pm 0.02$ & 4.17 \\
\hline & 4 & $4.00 \pm 0.15$ & 3.68 & $3.91 \pm 0.12$ & 3.15 \\
\hline & 20 & $19.39 . \pm 0.68$ & 3.52 & $19.77 \pm 0.82$ & 4.15 \\
\hline \multirow{4}{*}{ Liver } & 0.4 & $0.51 \pm 0.02$ & 3.50 & $0.51 \pm 0.02$ & 3.85 \\
\hline & 4 & $3.91 \pm 0.17$ & 4.44 & $3.84 \pm 0.16$ & 4.09 \\
\hline & 20 & $19.78 \pm 0.84$ & 4.25 & $19.19 \pm 0.63$ & 3.26 \\
\hline & 0.4 & $0.50 \pm 0.02$ & 4.02 & $0.49 \pm 0.02$ & 4.97 \\
\hline \multirow[t]{2}{*}{ Lung } & 4 & $3.94 \pm 0.15$ & 3.89 & $4.01 \pm 0.14$ & 3.57 \\
\hline & 20 & $19.78 \pm 0.84$ & 4.46 & $20.59 \pm 0.39$ & 1.87 \\
\hline \multirow{3}{*}{ Kidney } & 0.4 & $0.50 \pm 0.02$ & 3.63 & $0.50 \pm 0.02$ & 3.81 \\
\hline & 4 & $3.94 \pm 0.15$ & 3.75 & $3.90 \pm 0.13$ & 3.25 \\
\hline & 20 & $20.00 \pm 0.85$ & 4.23 & $20.42 \pm 0.77$ & 3.79 \\
\hline \multirow{3}{*}{ Stomach } & 0.4 & $0.50 \pm 0.03$ & 5.74 & $0.49 \pm 0.02$ & 4.23 \\
\hline & 4 & $4.06 \pm 0.17$ & 4.17 & $3.91 \pm 0.11$ & 2.91 \\
\hline & 20 & $19.38 \pm 0.70$ & 3.60 & $19.43 \pm 0.28$ & 1.46 \\
\hline \multirow{3}{*}{ Brain } & 0.4 & $0.49 \pm 0.03$ & 5.37 & $0.51 \pm 0.01$ & 2.27 \\
\hline & 4 & $3.90 \pm 0.12$ & 3.03 & $3.93 \pm 0.12$ & 3.02 \\
\hline & 20 & $20.01 \pm 0.61$ & 3.07 & $19.91 \pm 0.68$ & 3.39 \\
\hline \multirow{3}{*}{ Spleen } & 0.4 & $0.50 \pm 0.02$ & 3.84 & $0.50 \pm 0.02$ & 4.56 \\
\hline & 4 & $3.91 \pm 0.15$ & 3.71 & $3.83 \pm 0.10$ & 2.51 \\
\hline & 20 & $19.89 \pm 0.95$ & 4.77 & $20.47 \pm 0.92$ & 4.49 \\
\hline \multirow{3}{*}{$\begin{array}{l}\text { Reproductive } \\
\text { organ }\end{array}$} & 0.4 & $0.50 \pm 0.02$ & 3.94 & $0.50 \pm 0.02$ & 4.13 \\
\hline & 4 & $3.82 \pm 0.14$ & 3.62 & $3.79 \pm 0.16$ & 4.24 \\
\hline & 20 & $19.64 \pm 0.56$ & 2.86 & $19.56 \pm 0.80$ & 4.09 \\
\hline
\end{tabular}

Table 3: Stability of pogostone under different storage conditions in rat tissues

\begin{tabular}{|c|c|c|c|c|c|c|c|}
\hline \multirow{2}{*}{ Tissue } & \multirow{2}{*}{$\begin{array}{c}\text { Spiked } \\
\text { concertration } \\
(\mu \mathrm{g} / \mathrm{mL})\end{array}$} & \multicolumn{2}{|c|}{ Freeze-thaw stability } & \multicolumn{2}{|c|}{$\begin{array}{l}\text { Room temperature } \\
\text { stability }\end{array}$} & \multicolumn{2}{|c|}{ Long-term stability } \\
\hline & & $\begin{array}{c}\text { Mean } \pm S D \\
(\mu g / m L)\end{array}$ & $\begin{array}{c}R S D \\
(\%)\end{array}$ & $\begin{array}{c}\text { Mean } \pm S D \\
(\mu g / m L)\end{array}$ & $\begin{array}{l}R S D \\
(\%)\end{array}$ & $\begin{array}{c}\text { Mean } \pm S D \\
(\mu g / m L)\end{array}$ & RSD (\%) \\
\hline \multirow{3}{*}{ Heart } & 0.4 & $0.48 \pm 0.02$ & 3.17 & $0.50 \pm 0.02$ & 4.16 & $0.50 \pm 0.02$ & 3.42 \\
\hline & 4 & $3.91 \pm 0.11$ & 2.86 & $4.07 \pm 0.16$ & 4.04 & $4.06 \pm 0.13$ & 3.32 \\
\hline & 20 & $19.96 \pm 0.41$ & 2.07 & $20.72 \pm 0.33$ & 1.61 & $20.41 \pm 0.80$ & 3.93 \\
\hline \multirow{3}{*}{ Liver } & 0.4 & $0.52 \pm 0.01$ & 2.47 & $0.53 \pm 0.01$ & 2.23 & $0.52 \pm 0.02$ & 2.93 \\
\hline & 4 & $3.91 \pm 0.18$ & 4.57 & $3.91 \pm 0.17$ & 4.45 & $3.86 \pm 0.13$ & 3.48 \\
\hline & 20 & $20.42 \pm 0.73$ & 3.55 & $20.22 \pm 0.97$ & 4.79 & $19.97 \pm 0.85$ & 4.24 \\
\hline \multirow{3}{*}{ Lung } & 0.4 & $0.49 \pm 0.02$ & 4.68 & $0.52 \pm 0.03$ & 4.86 & $0.50 \pm 0.02$ & 3.82 \\
\hline & 4 & $3.99 \pm 0.09$ & 2.21 & $3.94 \pm 0.12$ & 2.92 & $4.05 \pm 0.19$ & 4.78 \\
\hline & 20 & $19.75 \pm 0.37$ & 1.89 & $19.39 \pm 0.41$ & 2.10 & $20.14 \pm 0.83$ & 4.14 \\
\hline \multirow{3}{*}{ Kidney } & 0.4 & $0.49 \pm 0.02$ & 4.16 & $0.50 \pm 0.02$ & 4.97 & $0.49 \pm 0.01$ & 2.9 \\
\hline & 4 & $4.05 \pm 0.10$ & 2.37 & $3.93 \pm 0.10$ & 2.45 & $4.07 \pm 0.17$ & 4.15 \\
\hline & 20 & $19.67 \pm 0.82$ & 3.55 & $20.49 \pm 0.98$ & 4.81 & $20.10 \pm 0.85$ & 4.25 \\
\hline \multirow{3}{*}{ Stomach } & 0.4 & $0.51 \pm 0.02$ & 4.24 & $0.49 \pm 0.02$ & 3.8 & $0.50 \pm 0.02$ & 4.35 \\
\hline & 4 & $3.98 \pm 0.17$ & 4.17 & $3.95 \pm 0.13$ & 3.3 & $3.96 \pm 0.13$ & 3.19 \\
\hline & 20 & $19.65 \pm 0.76$ & 3.85 & $19.74 \pm 0.82$ & 4.16 & $20.59 \pm 0.54$ & 2.6 \\
\hline \multirow{3}{*}{ Brain } & 0.4 & $0.51 \pm 0.01$ & 2.24 & $0.52 \pm 0.01$ & 2.82 & $0.49 \pm 0.02$ & 4.17 \\
\hline & 4 & $3.91 \pm 0.13$ & 3.38 & $3.87 \pm 0.16$ & 4.08 & $3.96 \pm 0.14$ & 3.45 \\
\hline & 20 & $19.92 \pm 0.91$ & 4.58 & $19.67 \pm 0.63$ & 3.18 & $19.76 \pm 0.52$ & 2.64 \\
\hline \multirow{3}{*}{ Spleen } & 0.4 & $0.50 \pm 0.02$ & 3.31 & $0.48 \pm 0.02$ & 3.86 & $0.51 \pm 0.02$ & 3.16 \\
\hline & 4 & $3.93 \pm 0.06$ & 1.52 & $4.08 \pm 0.14$ & 3.42 & $4.05 \pm 0.16$ & 3.85 \\
\hline & 20 & $19.91 \pm 0.84$ & 4.21 & $19.94 \pm 0.40$ & 1.98 & $19.65 \pm 0.82$ & 4.18 \\
\hline \multirow{3}{*}{$\begin{array}{l}\text { Reproductive } \\
\text { organ }\end{array}$} & 0.4 & $0.51 \pm 0.02$ & 3.52 & $0.49 \pm 0.02$ & 4.31 & $0.49 \pm 0.02$ & 4.02 \\
\hline & 4 & $3.88 \pm 0.14$ & 3.55 & $3.85 \pm 0.12$ & 2.99 & $3.85 \pm 0.10$ & 2.48 \\
\hline & 20 & $19.82 \pm 0.94$ & 4.74 & $19.68 \pm 0.66$ & 3.36 & $19.21 \pm 0.72$ & 3.77 \\
\hline
\end{tabular}


Table 4: Extraction recovery and matrix effect of pogostone under different storage conditions in rat tissues

\begin{tabular}{|c|c|c|c|}
\hline Tissue & $\begin{array}{c}\text { Spiked } \\
\text { concertration } \\
(\mu \mathrm{g} / \mathrm{mL})\end{array}$ & $\begin{array}{c}\text { Extracted } \\
\text { recovery } \\
(\%)\end{array}$ & RSD (\%) \\
\hline \multirow{3}{*}{ Heart } & 0.4 & $98.63 \pm 1.73$ & 1.76 \\
\hline & 4 & $97.73 \pm 2.39$ & 2.44 \\
\hline & 20 & $99.96 \pm 1.37$ & 1.37 \\
\hline \multirow{3}{*}{ Liver } & 0.4 & $101.16 \pm 2.59$ & 2.56 \\
\hline & 4 & $99.25 \pm 1.32$ & 1.33 \\
\hline & 20 & $99.11 \pm 2.98$ & 3 \\
\hline \multirow{3}{*}{ Lung } & 0.4 & $100.46 \pm 2.31$ & 2.3 \\
\hline & 4 & $96.94 \pm 3.98$ & 4.11 \\
\hline & 20 & $97.87 \pm 3.16$ & 3.23 \\
\hline \multirow{3}{*}{ Kidney } & 0.4 & $97.57 \pm 0.49$ & 0.5 \\
\hline & 4 & $98.20 \pm 1.29$ & 1.31 \\
\hline & 20 & $98.25 \pm 3.26$ & 3.32 \\
\hline \multirow{3}{*}{ Stomach } & 0.4 & $97.88 \pm 1.69$ & 0.62 \\
\hline & 4 & $97.72 \pm 2.90$ & 2.97 \\
\hline & 20 & $100.07 \pm 0.62$ & 1.73 \\
\hline \multirow{3}{*}{ Brain } & 0.4 & $94.43 \pm 2.05$ & 1.49 \\
\hline & 4 & $96.30 \pm 3.33$ & 3.45 \\
\hline & 20 & $96.19 \pm 1.43$ & 2.17 \\
\hline \multirow{3}{*}{ Spleen } & 0.4 & $97.93 \pm 1.21$ & 1.23 \\
\hline & 4 & $99.91 \pm 2.62$ & 2.62 \\
\hline & 20 & $98.43 \pm 1.76$ & 1.79 \\
\hline \multirow{3}{*}{$\begin{array}{l}\text { Reprodu } \\
\text { ctive } \\
\text { organ }\end{array}$} & 0.4 & $96.81 \pm 3.23$ & 3.34 \\
\hline & 4 & $97.46 \pm 2.37$ & 2.43 \\
\hline & 20 & $98.43 \pm 4.80$ & 4.87 \\
\hline
\end{tabular}

The method described above was successfully applied to the determination of pogostone in different tissues from rats. The tissue distribution of $P O$ in rats at 15,60 and 360 min after i.v. administration of $10 \mathrm{mg} / \mathrm{kg}$ was presented in Figure 3 . In addition, $\mathrm{PO}$ tissue distribution in rats at 30,90 and 360 min after oral administration of $10 \mathrm{mg} / \mathrm{kg}$ was presented in Figure 4.

\section{DISCUSSION}

Drugs were absorbed into blood and followed by distributed into target tissues, and then the pharmacological actions were performed by the unbound fraction of each compound. Hence, the tissue distribution pattern of compounds combined to certain tissues could contribute to illuminating the metabolic pathways and evaluating the toxicity.

The tissue distribution of $\mathrm{PO}$ in rats at 15,60 and $360 \mathrm{~min}$ after i.v. administration of $10 \mathrm{mg} / \mathrm{kg}$ was presented in Figure 3. These data showed that
PO was detected in all tissues during the examination period, indicating that $\mathrm{PO}$ was distributed widely in rats.

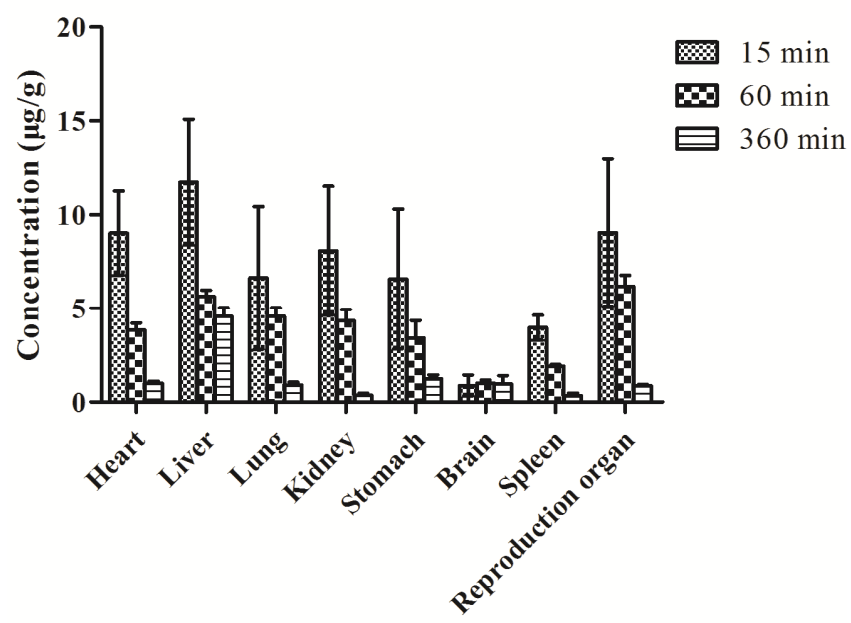

Figure 3: Tissue concentration of pogostone in various rat tissues after a single intravenous injection of $10 \mathrm{mg} / \mathrm{kg}$ dose

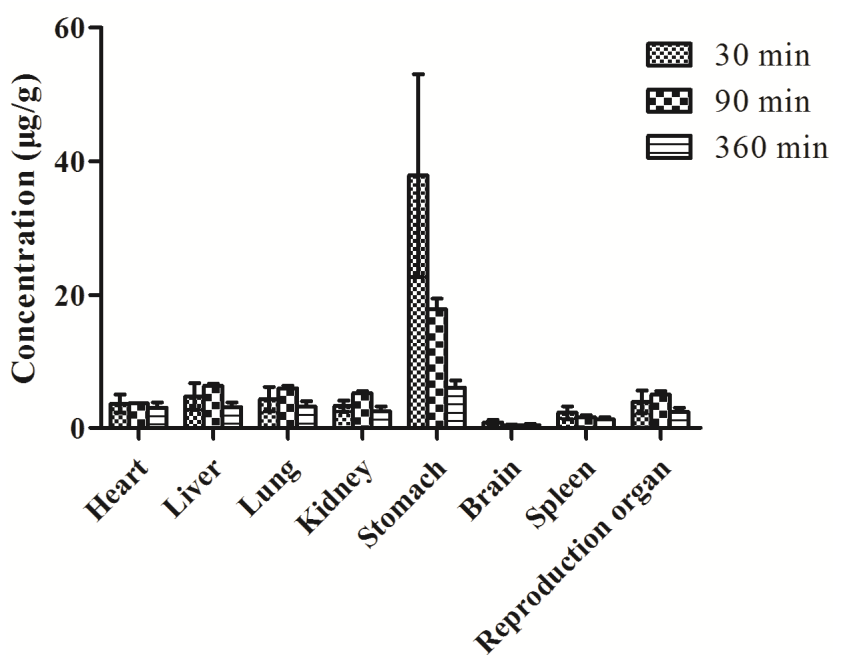

Figure 4: Tissue concentrations of pogostone in various rat tissues after a single oral administration of $10 \mathrm{mg} / \mathrm{kg}$ dose

The highest concentration was observed in the liver, followed by the reproductive organ, heart, kidney, lung, stomach, spleen and brain at 15 min after i.v. administration. As an abundant blood-supply tissue, liver tissue contained the largest amounts of $\mathrm{PO}(11.74 \mu \mathrm{g} / \mathrm{g})$ which implied that the distribution of this compound was depended on the blood flow and perfusion rate of this organ. Furthermore, this phenomenon suggested that PO was mainly absorbed and eliminated in liver. Reproductive organ, heart, kidney, lung, stomach and spleen contained moderate amounts of $\mathrm{PO}$ over the range of 3.96 9.05 $\mu \mathrm{g} / \mathrm{g}$. However, the level of PO $(0.88$ $\mu \mathrm{g} / \mathrm{g}$ ) in brain tissue was much lower than that of other tissues, which indicated that PO showed a 
weak capability on permeating the blood-brain barrier (BBB).

At 60 min after i.v. administration, reproductive organ tissue contained the largest amounts of PO, followed by the liver, lung, kidney, heart, stomach, spleen and brain. The concentration of $\mathrm{PO}$ in reproductive organ tissue reached up to $6.18 \mu \mathrm{g} / \mathrm{g}$ which indicated that PO might make a direct effect on target organs. And these results might be closely relevant to the anti-Candida albicans activity of PO in the vagina. Heart, lung, kidney, stomach and liver tissues contained moderate amounts of $\mathrm{PO}$ over the range of $1.88 \sim 5.62 \mu \mathrm{g} / \mathrm{g}$. The levels of $P O$ in heart, liver, kidney and spleen tissues were less than the half of that at $15 \mathrm{~min}$, which indicated that $\mathrm{PO}$ eliminated quickly in these tissues.

At 360 min after i.v. administration, the concentrations of $\mathrm{PO}$ in all tissues sharply declined over the range of $0.33 \sim 1.22 \mu \mathrm{g} / \mathrm{g}$. These data indicated that $P O$ could be distributed rapidly and widely, and eliminated rapidly with time, and there was no long-term accumulation, which in accordance with the variation trend of plasma concentration in the published literature [7] and our previous study.

$\mathrm{PO}$ tissue distribution in rats at 30,90 and 360 $\mathrm{min}$ after oral administration of $10 \mathrm{mg} / \mathrm{kg}$ was presented in Figure 4. At $30 \mathrm{~min}$ after oral administration, the highest level of $\mathrm{PO}$ was detected in stomach tissue $(37.91 \mu \mathrm{g} / \mathrm{g})$, and followed by liver, lung, reproductive organ, heart, kidney, spleen and brain. The concentration of $\mathrm{PO}$ in stomach tissue was almost eight-folds than that of other tissues. These data suggested that PO mainly absorbed in stomach tissue after oral administration and then entered in plasma, so as to distribute into other tissues. Accordingly, the concentrations of $\mathrm{PO}$ in other tissues (heart, liver, lung, kidney, spleen and reproductive organ) were relatively low over the range of 2.28 4.72 $\mu \mathrm{g} / \mathrm{g}$. In particular, brain tissue contained the least amounts of PO $(0.81 \mu \mathrm{g} / \mathrm{g})$, which is consistent with the results of intravenous administration. Hence, these data further confirmed that PO could hardly cross the BBB.

At 90 min after oral administration, the level of $\mathrm{PO}$ in stomach sharply reduced to $17.86 \mu \mathrm{g} / \mathrm{g}$. In spite of this, the stomach tissue still contained the highest concentration of PO, and followed by liver, lung, kidney, reproductive organ, heart, spleen and brain over the range of $0.41 \sim 6.25$ $\mu \mathrm{g} / \mathrm{g}$. The levels of PO in other tissues increased had smaller increase except for the brain and spleen tissues. Therefore, the above data further confirmed that PO was absorbed in stomach and then distributed into other tissues after oral administration.

At 360 min after oral administration, the levels of $\mathrm{PO}$ in all the tissues declined sharply with the concentration over the range of $0.45 \sim 6.05 \mu \mathrm{g} / \mathrm{g}$, whereas stomach tissue still contained the highest amounts of PO. Compared with the results of intravenous administration of $\mathrm{PO}$ in rat, PO was eliminated more slowly after oral administration.

\section{CONCLUSION}

A rapid, sensitive and reliable UFLC method for the determination of $\mathrm{PO}$ in rat tissues has been successfully developed and validated. The assay method affords good extraction recovery, sensitivity, stability, accuracy and precision, with short assay run time of 5 min. Furthermore, the injection volume is small. This method may also be useful for PO tissue distribution modeling studies in other animal models.

\section{ACKNOWLEDGEMENT}

This work was supported by grants from the National Natural Science Foundation of China (no. 81173534), Guangdong International Cooperation Project (no. 2012B050300002), Science and Technological Program for Dongguan's Higher Education, Science and Research, and Health Care Institutions (no. 2012105102009), Ph.D. Programs Foundation of Ministry of Education of China (no. 20134425110009) and Science and Technology Innovation Project of Guangdong Provincial Department of Education (no. 2013KJCX0045), and Science and Technology Planning Project of Guangdong Province (no. 2012A080202002) and the Special Funds from Central Finance of China in Support of the Development of Local Colleges and University [Educational finance Grant no.276(2014)]. Hai-ming Chen and Lan Wang contributed equally to this work.

\section{REFERENCES}

1. National Pharmacopoeia Commission, Eds. Pharmacopaeia of the People Republic of China. Beijing: Chemical Industry Press; 2010; $p 42$.

2. Zeng Z, Tan LX, Meng SJ, Zhang H. Study on the Chemical Constituents and Fingerprint of Pogostemon Cablinfrom Three Culture Varieties, Dermatophagoides farinae. Chin J Anal Chem 2006; 34(9): 1249-1254.

3. Wu HQ, Li L, Li J, He ZD, Liu ZG, Zeng QQ, Wang YS. Acaricidal activity of $D H E M H$, derived from patchouli 
oil, against house dust mite, Dermatophagoides farinae. Chem Pharm Bull (Tokyo) 2012; 60(2): 178182.

4. Yang ZX, Xie PS, Traditional chinese medicine Pogostemon cablin anti-fungal component-isolation and determination of structure of pogostone, Chinese Science Bulletin 1977; 22(7): 318-320.

5. Li YC, Liang HC, Chen HM, Tan LR, Yi YY, Qin Z, Zhang WM, Wu DW, Li CW, Lin RF, et al. Anti-Candida albicans activity and pharmacokinetics of pogostone isolated from Pogostemonis Herba. Phytomedicine 2012; 20(1): 77-83.

6. Wu YJ, Zheng YL, Chen N, Luan LJ, Liu XS. Plasma pharmacokinetics and tissue distribution study of physalin $D$ in rats by ultra-pressure liquid chromatography with tandem mass spectrometry. $J$ Chromatogr B 2011; 879(5-6): 443-448.

7. Chen HM, Li YC, Wu XL, Li CW, Li QG, Qin Z, Yi YY, Chen JN, Lai XP, Su ZR. LC-MS/MS determination of pogostone in rat plasma and its application in pharmacokinetic studies. Biomed Chromatogr 2013; 27(9): 1092-1099.

8. Prasain JK, Peng N, Moore R, Arabshahi A, Barnes S, Wyss JM. Tissue distribution of puerarin and its conjugated metabolites in rat tissues by liquid chromatography tandem mass spectrometry. Phytomedicine 2009; 16(1): 65-71.

9. Lowe PJ, Hijazi Y, Luttringer O, Yin $H$, Sarangapani $R$, Howard $D$. On the anticipation of the human dose in first-in-man trials from preclinical and prior clinical information in early drug development. Xenobiotica 2007; 37(10-11): 1331-1354.
10. Chen HM, Yi YY, Peng SZ, Qin Z, Wu XL, Li YC, Lai XP, Su ZR, Determination of pogostone in Pogostemon cablin (Blanco) Benth. by HPLC, J Guangzhou Univ Tradit Chin Med 2011; 28(6): 645-647.

11. Wang XG, Mo XL, Cai YW, Chen YZ. Content comparision of patchouli alcohol and pogostone inPogostemon cablin (Blanco)Benth. produced by tissue culture and cutting propagation. Chin J Pharm Anal 2009; 29(1): 96-99.

12. Wei G, Li W, Xu Hh. Study on GC-MS fingerprint analysis of volatile oil of Pogostemon cablin(Blanco) Benth. Cultivated in GAP Plot. Chin Tradit Pat Med 2003; 25(2): 90-94.

13. Guan J, Lai CM, Li SP. A rapid method for the simultaneous determination of 11 saponins in Panax notoginseng using ultra performance liquid chromatography. J Pharm Biomed Anal 2007; 44(4): 996-1000.

14. Fekete S, Fekete J, Ganzler K. Validated UPLC method for the fast and sensitive determination of steroid residues in support of cleaning validation in formulation area. J Pharmaceut Biomed Anal 2009; 49(3): 833-838

15. Liu X, Zhi H, Du F, Ye Z, Wang N, Qin W, Li J. A HPLCUV method for the determination of puerarin in rat plasma after intravenous administration of PEGylated puerarin conjugate. J Chromatogr B Analyt Technol Biomed Life Sci 2010; 878(31): 3297-3302.

16. Chinese Association For Laboratory Animal Sciences. Guidelines to Good Practice in Laboratory Animals Feeding and Management. 2009. 